\title{
The effect of a prototype hydromulch on soil water evaporation under controlled laboratory conditions
}

\author{
Antoni M.C. Verdú ${ }^{1}$, M. Teresa Mas ${ }^{1}$, Ramon Josa ${ }^{1}$, Marta Ginovart ${ }^{2 *}$ \\ ${ }^{1}$ Department of Agri-Food Engineering and Biotechnology, Universitat Politècnica de Catalunya, C/ Esteve Terradas 8, \\ 08860-Castelldefels, Barcelona, Spain. \\ 2 Departament of Mathematics, Universitat Politècnica de Catalunya, C/ Esteve Terradas 8, 08860 Castelldefels, Barcelona, Spain. \\ * Corresponding author. Tel.: +34 935521 133. Fax: +34 935521 122. E-mail: marta.ginovart@upc.edu
}

\begin{abstract}
Organic hydromulches can be an interesting alternative for weed control in perennial crops, but can also reduce soil water evaporation. To examine the effect of a hydromulch layer on soil water content in dry conditions laboratory experiments were conducted at constant $25^{\circ} \mathrm{C}, 40 \%$ air RH. Both for small soil containers with a short time course and for larger soil columns (with two sensors at depths of $6 \mathrm{~cm}$ and $11 \mathrm{~cm}$ ) with a longer time course, the presence and also the thickness of hydromulch were significant factors for the temporal evolution of soil water content. Two distinct stages of the evaporation process, the first or initial stage and the last or final stage, were identified, analysed and compared for these experiments. General linear models performed on the soil water content temporal evolutions showed significant differences for the first and last stages at the top and bottom of the soil columns with and without hydromulch. Hydromulch application delayed the evaporation process in comparison with the control. Moreover, the hydromulch layer, which was tested for mechanical resistance to punching, offered enough resistance to prevent its perforation by the sprouts of weed rhizomes.
\end{abstract}

Keywords: Byproducts reuse; Punching resistance; Sandy loam soil; Water conservation; Weeds.

\section{INTRODUCTION}

It is well recognized that the main challenge facing the sustainability of water management in agriculture is to improve the efficiency of water use and its sustainability. This is an objective that is pursued worldwide. There are several management practices for increasing water use efficiency, one of them being mulching (Biswas et al., 2015). In particular, this is important in rain-fed crop cultivation (Kader et al., 2019). These authors list a series of benefits that the use of mulch in agriculture can provide, both from an edaphic environmental perspective (conservation of soil water, reduction of water evaporation, improvement of water holding capacity, soil temperature regulation, pest control, minimization of weed effects, increase in nutrient status) and from an economic one (enhancement of crop yields, increase in fruit quality, higher water use efficiency, earlier crop harvests).

Kasirajan and Ngouajio (2012) define mulching as a covering material over the soil surface. There are many types of mulching. An initial classification reflects the kind of materials employed: organic or inorganic (Kader et al., 2017; Pramanik et al., 2015).

It is evident that plastics have been the materials most commonly used as mulch in agriculture in recent decades. As Steinmetz et al. (2016) comment, this practice provides interesting economic benefits and increases water use efficiency. Kasirajan and Ngouajio (2012) summarize a very interesting history of plastic mulch. However, at present it is accepted that the use of non-degradable plastics, in particular polyethylene, represents a serious environmental problem since it poses a significant risk for the sustainability of the ecosystem in agricultural lands (Steinmetz et al., 2016).

Photodegradable and biodegradable plastics to be used as mulch have been developed since the 1960s and 1980s, respec- tively, as an environmentally friendly alternative to synthetic mulches. Biodegradable plastics designed to be tilled into the soil after use (Bandopadhyay et al., 2018) are particularly interesting. Nevertheless, as Sintim et al. (2019) point out, there is limited information on the possible repercussions of biodegradable mulches on soil health. And in spite of a great deal of research in the area of biodegradable plastics, it is important to bear in mind that, in general, there is a serious economic limitation to using them at farm level due to the high cost of these plastics (Kasirajan and Ngouajio, 2012).

Taking into account the above, it is not surprising that the use of organic mulches has returned to the fore. Organic byproducts, crop, pruning or clearing remains, woodchips and pine bark have been used as mulches for many years (Zribi et al., 2015). As Rico Hernández et al. (2016) indicate, it is extremely important to use plant waste mulch in such a way that all of its potential advantages are optimized. These authors mention, for example, that cereal straw facilitates aeration and the entry of water into the soil, but because it decomposes slowly and has low nitrogen content, adding some type of supplementary fertilizer to the soil to facilitate its subsequent mineralization is considered necessary. Shumova (2013) points out that in wet regions, evapotranspiration decreases when the soil is mulched with cereal straw, which can result in a certain disturbance of the natural structure of the hydrological cycle and possible overmoistening of soils. Not long ago the possibility of reusing paper as mulch was reconsidered (Haapala et al., 2014). This organic material was already employed before the era of plastics, although due to its characteristics it was normally used in formulations that involved paper coated with several materials (Haapala et al., 2014; Shogren, 2000).

Other possible alternative mulches are biodegradable materials applied as slurries (foam mulch, hydraulic mulches and hydromulches) (Warnick et al., 2006). In fact, the mode of 
application is based on hydromulching and hydroseeding technologies, used on burned slopes to prevent soil erosion or to foster revegetation. Claramunt et al. (2020) describes some aspects of the composition of a set of hydromulches, as well as their mechanical properties from the point of view of resistance to traction and punching forces. Likewise, the mentioned authors found that some hydromulches can efficiently prevent weed seedling emergence and reduce the seed bank.

In this study we are interested in presenting a slurry product that can be sprayed on the soil surface of crop fields. This prototype of hydromulch has been developed by mixing several substances, as detailed in Claramunt et al. (2020), including paper pulp and crop residues, waste products that can be reused. Although it was initially thought of as a weed control system, it should provide possibilities from the point of view of soil protection (Rico Hernández et al., 2016). According to McMillen (2013) the use of hydromulches, as a type of organic mulches, can result in higher water use efficiency by preventing soil evaporation, increasing the soil water holding capacity due to the decomposition of the hydromulch, and reducing the undesirable impact of raindrops and water runoff and the severity of certain diseases, among others.

In many agricultural areas available water, together with soil mechanical resistance (Letey, 1985), is essential for agricultural practices. Nowadays, the principles of conservation agriculture emphasize the importance of the soil and explicitly cite the need for water conservation (Dumanski et al., 2006). Therefore, many strategies have been used to optimize soil water content, particularly in arid and semiarid lands (Jones et al., 1969), by minimizing the amount of water lost from the soils through evaporation (CTCN, 2019). On the other hand, some experiments carried out in non-agricultural lands suggest the interest in using water repellent soil materials (duff) as mulch layers in order to reduce soil water evaporation ratio in sandy and clayloam soils of the central part of the Mediterranean area (Lichner et al., 2020).

Zribi et al. (2015) document the effectiveness of inorganic and organic mulches in preventing soil evaporation in numerous annual crops. Likewise, Martín-Closas et al. (2016) mention the advantages of mulching utilization in tree crops. Successive stages of the soil drying process were described (Balugani et al., 2018; Han et al., 2017) after a field application of mulch, according to the balance between soil water potential and atmospheric capacity. Consequently, application of mulch in field conditions can modify the water dynamics of the whole profile. But hydromulch also generates a more or less continuous layer that can harden. So, under some conditions, when hydromulch dries it could become a layer opaque enough to prevent weed seed germination and rhizome sprouting or it could become hard enough to be impenetrable for weed seedlings or sprouts.

The aim of this paper is to understand how the hydromulch affects soil water evaporation and mechanical stress in the soilatmosphere interface. We focus on topsoil behaviour after the application of hydromulch under laboratory conditions simulating extreme dry conditions, from both a hydrological and a mechanical point of view.

\section{MATERIAL AND METHODS \\ Environmental conditions, soil and hydromulch characteristics}

All the experiments were performed in a climatic chamber (Radiber GERHR-700 ESP) at constant $25^{\circ} \mathrm{C}, 40 \%$ air RH, and $12 \mathrm{~h}$ light / $12 \mathrm{~h}$ dark daily cycle, simulating the dry extreme conditions that can occur in the western Catalonia (NE Spain) vineyard and fruit orchard production zones towards the end of May and June (Meteocat, 2019).

Four experiments were performed to compare the loss of water by evaporation from wet soil with and without a mulch cover. A preliminary experiment was conducted, on a small scale and short in time, to observe the possible effect of mulch thickness, using $13.5 \mathrm{~cm}$ internal diameter $\mathrm{x} 10 \mathrm{~cm}$ height glass cylinders. Small samples helped us to understand the hydromulch drying process and to verify the mechanical behaviour of the hydromulch, in particular whether dry cracking would occur. The other three experiments, on a larger scale and longer in time, named experiments 1,2 and 3, used $29.5 \mathrm{~cm}$ internal diameter $\times 25 \mathrm{~cm}$ height plastic columns equipped with soil moisture, water potential and temperature sensors. The soil employed in all experiments was air dried and sieved $(<2 \mathrm{~mm})$. It was a sandy loam (tending towards sandy clay loam; $62.5 \%$ sand, $19.3 \%$ silt, and $18.1 \%$ clay) obtained from the Ap horizon of a calcareous soil. In the experiments the bulk density of the packed soil was $1400 \mathrm{~kg} \mathrm{~m}^{-3}(\mathrm{CV}=4.38 \%)$ and its porosity was $0.47 \mathrm{~m}^{3} \mathrm{~m}^{-3}$; no mechanical forces were applied to the soil, other than gravity. Soils in the containers were irrigated with distilled water over saturation (preliminary experiment) or field capacity for the other three experiments $\left(0.221 \mathrm{~m}^{3} \mathrm{~m}^{-3}\right.$ according to Saxton et al. 1986). Whatever the sample size, there were two types of situations: soil, and soil + hydromulch. A ring of rubber sealing strip was placed around the inner top perimeter of both types of containers, just above the soil or the mulch, in order to avoid water evaporation through the space between the content and the container walls. The monitoring of the experiments started just after the hydromulch was applied.

The hydromulch employed was applied as a liquid heterogeneous paste. It was a mixture of four components: (i) paper pulp supplied by Saica, a paper mill in Zaragoza (Spain) that manufactures recovered waste paper and cardboard; (ii) wheat straw cut in a mill and sieved at $2 \mathrm{~mm}$; (iii) powdered gypsum type B1, at less than $4.5 \%$ by weight; and (iv) kraft pulp from Pinus radiata D. Don supplied by Pacifico BSKP. The density of the hydromulch varied between 1030 and $1120 \mathrm{~kg} \mathrm{~m}^{-3}$, depending on the proportion of water and fibres of the paper pulp. Just after an application, around $21 \%$ of the weight of the hydromulch was lost in the form of liquid that drained down by gravity. This amount of liquid was taken into consideration to calculate the soil water content ( $\mathrm{vol} / \mathrm{vol})$ of the samples having hydromulch treatment. After the mentioned rapid loss, the mean bulk density of the moist hydromulch layer was $66.9 \mathrm{~kg} \mathrm{~m}^{-3}$ $(\mathrm{CV}=13.6 \%)$. After that, during the course of the experiments, the hydromulch slowly lost its water until it became a drier, hardened solid mulch. Under the experiments' environmental conditions, it took six days for a sample of hydromulch without soil to lose as much water as in an oven at $105^{\circ} \mathrm{C}$ for $24 \mathrm{~h}$, giving a mean bulk density value of $18.8 \mathrm{~kg} \mathrm{~m}^{-3}(\mathrm{CV}=7.8 \%)$.

\section{Small sample experiment}

During the experiment all data on water evaporation were obtained by weighing the 12 small samples, which were filled with soil from the bottom to a height of approximately $4.5 \mathrm{~cm}$, and adding water until soil saturation. Two levels of hydromulch were tested, SH_10 and SH_16, corresponding to doses of $9.9(0.14) \mathrm{kg} \mathrm{m}^{-2}$ and $15.8(0.12) \mathrm{kg} \mathrm{m}^{-2}$, these numbers being the mean doses and their standard errors (SE, standard deviation of the mean) in parentheses. Each level of hydromulch was represented by three containers, while six containers were used as controls. The two doses of hydromulch applied became layers of approximately $10 \mathrm{~mm}$ and $20 \mathrm{~mm}$ in 
thickness when wet, just after their application, but the thinner had reduced to 8.1 (SE 0.38) $\mathrm{mm}$ and the thicker to 15.2 (SE $0.52) \mathrm{mm}$ on average by the end of the experiment.

The experiment lasted 8 days (190 hours); eight weight values were taken during the period. The relative position of the samples within the chamber was changed daily, ensuring that all of them experienced intra-chamber variability with respect to evaporative demand, because it was noted previously that, at the temperature and air RH employed, the water evaporation rate (evaporative demand) ranged between $6.4 \mathrm{~mm} \mathrm{day}^{-1}$ and $3.8 \mathrm{~mm} \mathrm{day}^{-1}$, depending on the particular zone within the chamber; there was a gradient between the zone close to the door (drier) and the zone far from the door (wetter).

Three variables related to water evaporation were obtained and analysed: (1) accumulated water loss (weight), (2) relative water loss ( $\mathrm{vol} / \mathrm{vol})$, that is, initial water content minus final content relative to initial, and (3) daily evaporation $\left(\mathrm{mm} / \mathrm{day}^{-1}\right)$, computed from the difference between the water content for the intervals of time measured.

One-way analysis of variance followed by Tukey's multiple comparison test were performed with the arcsine-transformed relative water loss values. The only source of variation was the treatment, with three levels: control, thin hydromulch, and thick hydromulch. General linear models (GLM) and variance tests (ANOVA) were used to evaluate the influence of the factor treatment on the temporal evolution of the daily evaporation.

\section{Column experiments}

The columns employed were lined at the bottom with $3 \mathrm{~cm}$ thickness expanded clay covered by a non-woven geotextile for drainage. Over this layer they were filled with soil up to a thickness of $18 \mathrm{~cm}$, and were equipped with two sets of temperature (ECT/RT-1, Decagon devices), soil water content (ECH20, Decagon devices) and soil water potential sensors (MPS-6, Decagon devices), one at a depth of $6 \mathrm{~cm}$ (top) and other at $11 \mathrm{~cm}$ (bottom). The sensors were installed perpendicular to the soil column; soil water content was monitored as volume/volume (vol/vol) and soil water potential was measured in $\mathrm{kPa}$ each 6 hours. The temperature was monitored to check its stability. In each experiment three types of columns were placed in the climatic chamber: one column was the control (soil), the second had soil and hydromulch, and the third had soil, hydromulch and three non-dormant weed rhizomes buried $1 \mathrm{~cm}$ under the soil surface. The position of each type of column within the chamber was set at random for each experiment to take into account the intra-chamber variability in evaporative demand. Only one dose of hydromulch was employed, 18.5 (SE 0.8) kg $\mathrm{m}^{-2}$, producing a wet mulch layer around $23 \mathrm{~mm}$ thick at the beginning of the experiments and 12.3 (SE 0.35) $\mathrm{mm}$ at the end.

Rhizomes of Paspalum dilatatum Poiret in Lam., tubers of Cyperus rotundus L., and rhizomes of Sorghum halepense L. (Pers.), were employed in experiments 1,2 , and 3 respectively. Their mean sizes were $41 \mathrm{~mm}$ length and $9 \mathrm{~mm}$ diameter for $P$. dilatatum, $54 \mathrm{~mm}$ length and $12.8 \mathrm{~mm}$ diameter for $C$. rotun$d u s$, and $37 \mathrm{~mm}$ length and $7.8 \mathrm{~mm}$ diameter for $S$. halepense. The ability of the rhizomes (collected and cut similarly) to sprout and to perforate by punching a wet hydromulch layer was previously tested at $25^{\circ} \mathrm{C}$ and $12 \mathrm{~h}$ light $/ 12 \mathrm{~h}$ dark daily cycle (Figure 1).

The weights of the soil columns were taken at the beginning (together with that of each of the components) and at the end of each experiment. Just after the hydromulch application the experiments began inside the chamber, and the sensors were turned on.

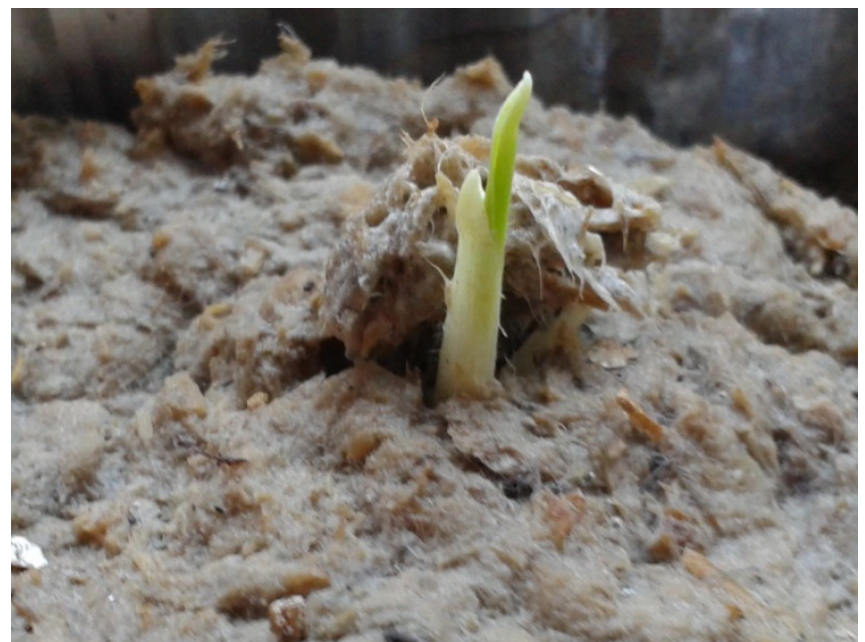

Fig. 1. Sprout of Sorghum halepense that had passed through a wet layer of the prototype hydromulch by punching it.

The experimental data were first analysed statistically using a set of exploratory techniques to investigate the relationship between the measured variables, the soil water potential and the soil water content with the two types of sensors. Regarding the temporal evolution of the soil water content in the columns, linear models were investigated for two different periods of time, the first days and the last, and it took into account various sets of data characterized by the measurement depth and by the treatment performed on the column. GLM and ANOVA were used to evaluate the influence of the factor under study, the presence or absence of mulch, on the temporal evolution of soil water content in these two periods of time, the first and the final stages, distinguishing the subsets of data by the recorded position of the sensor.

All data were analysed using SAS (SAS, 2013) and Minitab ${ }^{\circledR}$ Statistical Software (Minitab Inc., 2012). The probability level of significance was set at 0.05 .

\section{Hydromulch resistance to punching}

Punching tests were performed to determine the resistance (MPa) of the mulches at the end of the experiments, because this test could inform about the resistance of the hydromulch to being penetrated by the weed seedlings or sprouts. The equipment used was a Stable Micro Systems XT-plus Texture Analyser, with a probe $7.86 \mathrm{~mm}$ in diameter. The load cell of the analyser has a maximum capacity of $500 \mathrm{~N}$ and the cross head speed in the tests was $4 \mathrm{~mm} \mathrm{~min}^{-1}$. The punching test subsamples used were circular. They were obtained by cutting the hydromulch layers once, after the experiments in the chamber had finished, and they were removed from the soil surface at room temperature and humidity. Three punching tests were made with the mulch of each hydromulch layer, whether they were from the small sample experiment or from the three column experiments. The parameter resistance to punching was the maximum breaking strength or modulus of rupture, also called stress, which was obtained according to Claramunt et al. (2020).

\section{RESULTS AND DISCUSSION Experiment in small containers}

Relative losses in water content over the period with respect to initial moisture showed that the hydromulch layers caused a 
certain delay in the evaporation process and, at the same time, diminished the total amount of water losses by evaporation (Table 1, Figures 2-3). While the control showed a 98.3\% relative loss, the treatments with hydromulch presented lower mean values, $82.9 \%$ and $68.7 \%$, depending on the thickness of the mulch (Table 1). The one-way ANOVA test applied to the variable relative water loss showed the treatment was significant ( $\mathrm{p}$-value $<0.001$ ). In addition, the three means were significantly different from each other (Tukey method), the level with the thickest hydromulch having the lowest value.

Table 1. Mean values and their respective standard errors (SE) of the water contents registered in the small containers at the beginning $\left(\mathrm{WC}_{0}\right)$ and after 190 hours $\left(\mathrm{WC}_{190}\right)$ at $25^{\circ} \mathrm{C}$ and $40 \%$ air $\mathrm{RH}$. Control: soil without mulch; SH_10: soil with a thin mulch layer; SH_16: soil with a thick mulch layer.

\begin{tabular}{lcc}
\hline Treatment & $\mathrm{WC}_{0}(\mathrm{vol} / \mathrm{vol})(\mathrm{SE})$ & $\mathrm{WC}_{190}(\mathrm{vol} / \mathrm{vol})(\mathrm{SE})$ \\
\hline No mulch & $0.422(0.002)$ & $0.007(0.001)$ \\
Mulch SH_10 & $0.466(0.002)$ & $0.080(0.009)$ \\
Mulch SH_16 & $0.518(0.001)$ & $0.162(0.020)$ \\
\hline
\end{tabular}

Figure 2 describes the evolution of the accumulated water losses of the three treatments. The initial water applied was the same in all the small containers, but hydromulch, as a water slurry, included an additional dose of water in both SH 10 and SH_16 levels. Two periods in the temporal evolution of the water evaporation can be considered, one for the first three days and the other for the last three days, since the values in the initial stage were higher than those in the final stage, when a clear decrease in the evaporation took place (Figure 3). Teng et al. (2013) also consider two stages in the soil water evaporation process: a constant-rate stage, which occurs when the soil surface is at or near saturation and is controlled by atmospheric conditions; and a falling-rate stage in which the water movement is controlled by the soil water potential. In the initial stage, the linear regression model for the daily evaporation and time was non-significant (Figure 3), there was no significant effect for time in this period of the temporal evolution ( $p$-value $=0.099)$ and, at the same time, there were no significant differences between constants for the three treatments ( $p$-value $=$ 0.154). Nevertheless, in the final stage (Figure 3) significant differences were detected between the three linear regression

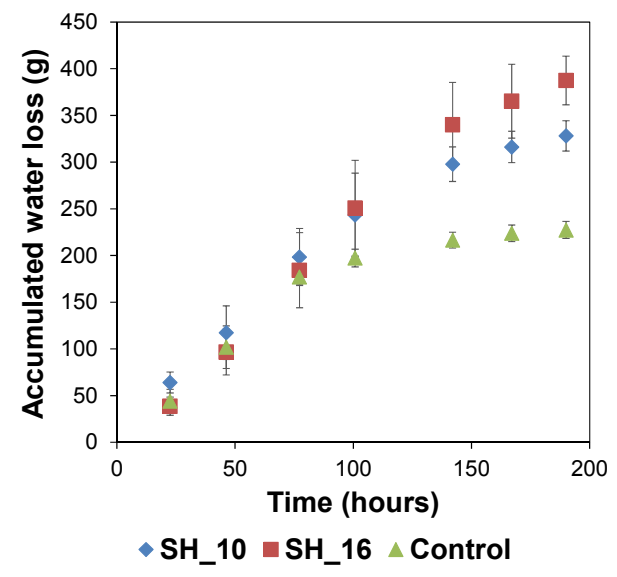

Fig. 2. Temporal evolution of the mean accumulated water losses in small containers in an experiment conducted under controlled conditions $\left(25^{\circ} \mathrm{C}, 40 \%\right.$ air $\left.\mathrm{RH}\right)$ to study the effect of the two hydromulch levels on the drying process (SH_10 and $\mathrm{SH}_{-} 16$ ). Standard deviations have been reported in the error bars.

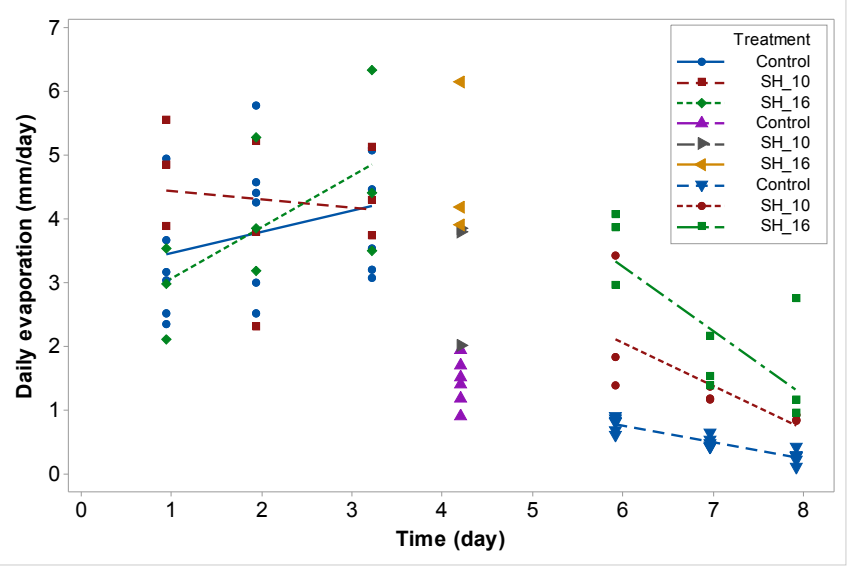

Fig. 3. Temporal evolution of surface evaporation and fitted regression lines obtained for each of the levels of the treatment, distinguishing the first and the last stages, in an experiment conducted in a chamber under controlled conditions $\left(25^{\circ} \mathrm{C}, 40 \%\right.$ air $\mathrm{RH})$ to study the effect of the hydromulch.

models for the constants of the adjusted regression lines $(p$-value $=0.001)$ and for their slopes $(p$-value $=0.013)$.

Differences between daily water evaporation slopes would suggest that the water evaporation rate was reduced when hydromulch was applied. The slopes corresponding to the $\mathrm{SH}_{-} 10$ and SH 16 mulch treatments were -0.68 and -1.02 respectively, whereas the slope for the control was -0.26 . Thus, the hydromulch tested favoured water retention in the soil, as do most other organic mulches (Haapala et al., 2014; Rico Hernández et al., 2016; Zribi et al., 2015), but, interestingly, the water loss diminished with mulch thickness (Table 1, Figure 2), which is a trait directly linked with another important quality of the mulches: their lifetime (O’Brien et al., 2018).

\section{Experiments in columns}

In all three experiments the weed rhizomes sprouted, but none of them was able to perforate the mulch layer. Due to the behaviour of the rhizomes, the soil water content versus soil water potential curves were very similar (Figure 4), because no transpiration occurred.

According to the weight values, the soil water contents at the beginning of experiment 1 were near to saturation, between 0.36 and $0.40 \mathrm{~kg} \mathrm{~kg}^{-1}$, while in the other two experiments (2 and 3) they were lower, between 0.24 and $0.27 \mathrm{~kg} \mathrm{~kg}^{-1}$. At the end, the soil water contents were, respectively, between 0.09 and $0.16 \mathrm{~kg} \mathrm{~kg}^{-1}$ in experiment 1 , and between 0.07 and 0.11 $\mathrm{kg} \mathrm{kg}^{-1}$ in experiments 2 and 3 . They lasted 23 days, 32 days, and 29 days respectively. So, the range of soil water content in experiment 1 was greater than those of the other experiments (Figure 4). In view of these differences, added to the nonemergence of any weed sprout, the detailed comparisons of the water evaporation of the columns with and without hydromulch were performed considering only the columns of experiments 2 and 3 placed in particular chamber sites with similar evaporative demand.

The hydromulch participated in the water evaporation of the system in two ways. Soil water content did not increase noticeably at the beginning of the experiment (Figure 4). A gradual drying process of the hydromulch took place by water transfer to the underlying soil and by evaporation. The drying process of the hydromulch decreases its water content (and its water potential) until an equilibrium is reached with the controlled atmosphere of the chamber. The transition took place around 

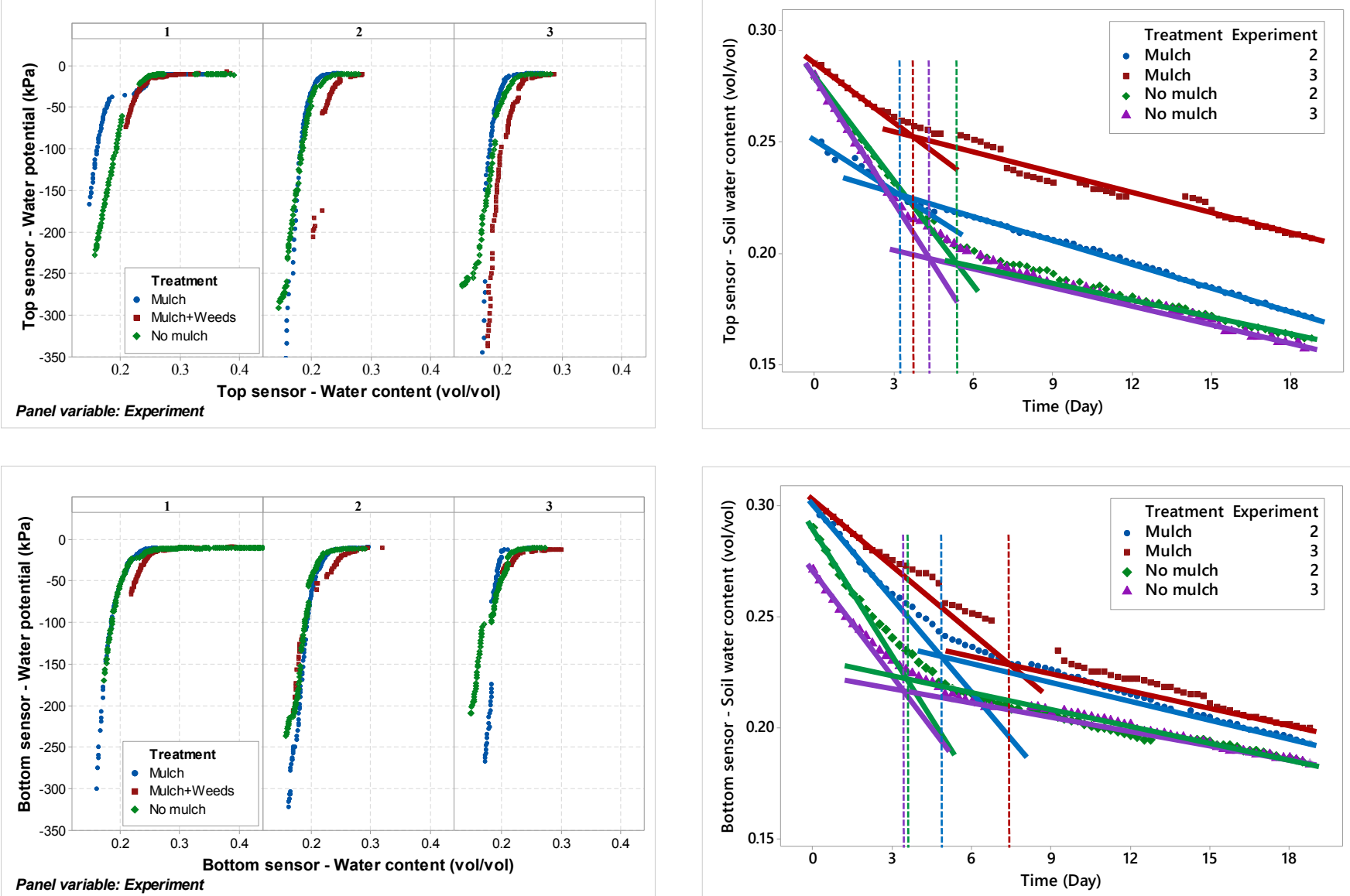

Fig. 4. Soil water potential versus soil water content of the top and bottom for the three levels of the factor treatment in the three experiments performed with soil columns in a chamber under controlled laboratory conditions $\left(25^{\circ} \mathrm{C}, 40 \%\right.$ air $\left.\mathrm{RH}\right)$.

$-25 \mathrm{kPa}$ to $-30 \mathrm{kPa}$, depending on the column and the soil depth. While at the top sensor of the control columns the minimum water potential measured was between $-200 \mathrm{kPa}$ and $-300 \mathrm{kPa}$, in the columns with mulch water potential achieved values lower than $-600 \mathrm{kPa}$ (data not shown, Figure 4). The water loss rate was lower in the bottom zone, because during the same period of time water potential achieved values of around $-300 \mathrm{kPa}$ and, at the same time, those from columns with mulch and without mulch were similar (Figure 4). Although our experiment was carried out at very low air RH, there are parallelisms with the results obtained in field and other laboratory conditions by several authors (Balugani et al., 2018; Han and Zhou, 2013; Han et al., 2017; Qiu and Ben-Asher, 2010; Teng et al., 2013; Zhang et al., 2015; Zribi et al., 2015), who found that the evaporation process from soils can be divided into a number of stages (between two and four) depending on the evolution of water potential and soil water content. Figure 4, jointly with Figure 5 showing the temporal evolution of water content, suggests that, in our experiments, two noticeable and clear stages could straightway be considered in the columns (with and without mulch), and they can be identified as the first or initial period and the last or final period of these temporal evolutions.

Figure 5 displays the temporal evolution of the soil water content for the period of the first 18 days. Two different behaviours of the water loss ratio are observed in all cases, with transient values between them. The slopes of the first and last part of the data evolve differently depending on the treatment.

Fig. 5. Temporal evolution of the soil water content (vol/vol) for the period of 18 days under controlled laboratory conditions $\left(25^{\circ} \mathrm{C}\right.$, $40 \%$ air $\mathrm{RH}$ ) with the fitted regression lines achieved considering the subdata of the initial stage and the final stage for each part (top and bottom) of the soil columns corresponding to the two experiments (2 and 3) and the presence or absence of mulch. The intersection of the two fitted regression lines corresponding to each temporal evolution is also displayed.

The characterization of the first stage by a linear model was accomplished with the subset of chosen data having approximately constant values for the differences of consecutive soil water content measurements to ensure and guarantee a stage with a linear decrease. The linear model for the characterization of the final stage was established with a regression using the data corresponding to the last three days $(16,17$ and 18) in all experiments, since it had been confirmed that all columns had already entered into the last part of the evaporation process during those days.

For each subset of data combining the sensors (bottom, top) and these two stages (initial and final), four GLMs were carried out to fit least squares models for the variable soil water content as the continuous response, with mulch as the categorical factor (yes / no) and time as the covariate, and considering the interaction between time and factor. Significant differences in each of the four ANOVA tables performed were detected in terms of the interaction of the factor mulch over time (slope of the regression line) with $\mathrm{p}$-values less than 0.01 , and the $\mathrm{R}^{2}$ values showed that the model explained more than $99 \%$ of the variance in soil water content. The linear model fitted the data very well in all four combinations. Figure 5 shows the fitted regression equations obtained by each sensor, differentiating the cases with and without mulch for the first and last stage. For 
the top of the column, the slopes of the regression lines for water content in the first stage were around -0.02 in the case of non-mulch whereas in the case of mulch they were around -0.01 , but in the last stage the coefficients of the slopes were much more similar and both with and without mulch were around -0.003 . With respect to the bottom of the column (for the initial and final stages), the interception at the origin of the regression lines indicates that with mulch these values (around 0.30 and 0.25 respectively) are higher than without mulch (around 0.28 and 0.23 respectively). The final water content that was reached was higher in the columns with mulch, although their slopes or evaporation rates were similar. In addition, the fitted regression lines resulting from the use of the last subsets of data (days 16, 17 and 18) make it possible to display periods of time with constant evaporation, periods that differ between experiments, but which are not restricted to only the last three days like the plotted regression lines shown (Figure 5). The intersection of the two regression lines corresponding to the first and final stages represents the time when the water evaporation regime changes from fast to the slowest rate after irrigation. This interval is shorter in the top part of the two columns with hydromulch than in the columns without hydromulch. On the other hand, the water content in the bottom part of the hydromulch columns is higher than in the columns without hydromulch at this time.

So, applying hydromulch in these experimental conditions favours an early reduction of the evaporation rate from the topsoil and at the same time a higher water content in the bottom part of these columns.

In the dry zone transport of water is merely as water vapour because the continuity of the water capillarity breaks down. The hydromulch layer on top of the soil surface could contribute to increase the role of the dry surface layer, which according to Han and Zhou (2013) has a significant impact on surface energy balance. In this way, the evaporation divides the soil into two parts, with only vapour flow occurring in the profile above the evaporation zone and liquid water flows mainly occurring in the profile below. It seems that there could be a connection between hydromulch and soil at the level of their respective pores.

\section{Hydromulch resistance to punching}

The mean resistance to punching of the mulches at the end of the experiments was 1.47 (SE 0.19) MPa. The mean force needed to perforate the mulch was $573.6 \mathrm{~N}$ in the columns, while those of the experiment in small samples were $264.6 \mathrm{~N}$ for SH_10, and $459.5 \mathrm{~N}$ for $\mathrm{SH}_{-}$16. These values, higher than those obtained by Claramunt et al. (2020), who tested several hydromulches containing also recycled paper pulp and lignocellulosic crop residues, could be considered promising, because no rhizome was able to perforate the mulch, and probably the small seeds of many weeds would not emerge if the mechanical impedance attained 0.5 MPa (Mas et al., 2017). But they are far from the $3.87 \mathrm{MPa}$ achieved by some black polyethylene plastics employed as agricultural mulches (Hosseinabadi et al., 2011).

\section{CONCLUSIONS}

In the very dry conditions tested, the mulch layer formed after hydromulch application delayed the evaporation process with respect to the control. In the experiment with small containers, the evaporation rate was lower the thicker the mulch.
Regarding water flow across the boundary between atmosphere and mulch-soil, the interest in the use of hydromulch lies in delaying the process by which the liquid water is converted into vapour and removed from the surface. Therefore, applying hydromulch could be useful both for delaying water evaporation and at the same time for controlling weeds by reducing emergence thanks to its mechanical behaviour.

Acknowledgements. This work was supported by the Instituto Nacional de Investigaciones Agrarias of the Spanish Government [grant numbers RTA2015-00047-C01 and RTA201500047-C04]. We would like to thank Dr. J. Claramunt for his assistance on mechanical tests, and S. Alcalá and M. Julià for their technical assistance. We are indebted to the companies that supplied the raw materials used to develop the prototype of the hydromulch.

\section{REFERENCES}

Balugani, E., Lubczynski, M.W., van der Tol, C., Metselaar, K., 2018. Testing three approaches to estimate soil evaporation through a dry soil layer in a semi-arid area. Journal of Hydrology, 657, 405-419.

Bandopadhyay, S., Martin-Closas, L., Pelacho, A.M., DeBruyn, J.M., 2018. Biodegradable plastic mulch films: impacts on soil microbial communities and ecosystem functions. Frontiers in Microbiology, Volume 9, Article Number 819.

Biswas, S.K., Akanda, A.R., Rahman, M.S., Hossain, M.A., 2015. Effect of drip irrigation and mulching on yield, wateruse efficiency and economics of tomato. Plant, Soil and Environment, 61, 3, 97-102.

Claramunt, J., Mas, M.T., Pardo, G., Cirujeda, A., Verdú, A.M.C., 2020. Mechanical characterization of blends containing recycled paper pulp and other lignocellulosic materials to develop hydromulches for weed control. Biosystems Engineering, 191, 35-47.

CTCN (Climate Technology Center \& Network), 2019. Connecting countries to climate technology solutions. $<$ https://www.ctc-n.org/technologies/soil-moistureconservation-techniques-0) $>$ [accessed 29 November 2019].

Dumanski, J., Peiretti, R., Benites, J.R., McGarry, D., Pieri, C., 2006. The paradigm of conservation agriculture. In: Proceedings of World Association of Soil and Water Conservation. Paper No. P1: 58-64.

Haapala, T., Palonen, P., Korpela, A., Ahokas, J., 2014. Feasibility of paper mulches in crop production: a review. Agricultural and Food Science, 23, 60-79.

Han, J., Zhou, Z., 2013. Dynamics of soil water evaporation during soil drying: laboratory experiment and numerical analysis. The Scientific World Journal, Article ID 240280, 10 pages.

Han, J., Lin, J., Day, Y., 2017. Numerical modeling of soil evaporation process and its stages dividing during a drying cycle. Geofluids, Article ID 5892867, 11 pages.

Hosseinabadi, F., Zebarjad, S.M., Mazinani, M., 2011. Investigation on perforation mechanism of medium density polyethylene. Materials Science Forum, 675-677, 387-390.

Jones, J.N., Moody, J.E., Lillard, J.H., 1969. Effects of tillage, no tillage, and mulch on soil water and plant growth. Agronomy Journal, 61, 719-721.

Kader, M.A., Senge, M., Mojid, M.A., Itob, K., 2017. Recent advances in mulching materials and methods for modifying soil environment. Soil \& Tillage Research, 168, 155-166.

Kader, M.A., Singha, A., Begum, M.A., Jewel, A., Khan, F.H., Khan, N.I., 2019. Mulching as water-saving technique in 
dryland agriculture: review article. Bulletin of the National Research Centre, 43, 147.

Kasirajan, S., Ngouajio, M., 2012. Polyethylene and biodegradable mulches for agricultural applications: a review. Agronomy for Sustainable Development, 32, 501-529.

Letey, J., 1985. Relationship between soil physical properties and crop production. In: Stewart, B.A. (Ed.): Advances in Soil Science, 1. Springer, New York, pp. 277-294.

Lichner, L', Alagna, V., Iovino, M., Laudicina, V.A, Novák, V., 2020. Evaporation from soils of different texture covered by layers of water repellent and wettable soils. Biologia. https://doi.org/10.2478/s11756-020-00471-5

Martín-Closas, L., Costa, J., Cirujeda, A., Aibar, J., Zaragoza, C., Pardo, A., Suso, M.L., Moreno, M., Moreno, C., Lahoz, I., Mácua, J.I., Pelacho, A.M., 2016. Above-soil and in-soil degradation of oxo- and bio-degradable mulches: a qualitative approach. Soil Research, 54, 2, 225-236.

Mas, M.T., Verdú, A.M.C., Ginovart, M., Josa, R., 2017. Seedling emergence through soil surface seals under laboratory conditions: effect of mechanical impedance and seal moisture. Biologia, 72, 862-868.

McMillen, M., 2013. The effect of mulch type and thickness on the soil surface evaporation rate. Horticulture and Crop Science Department, California Polytechnic State University, San Luis Obispo.

Meteocat. Servei Meteorològic de Catalunya, 2019. Normals climàtiques recents. URL <http://www.meteo.cat/wpweb/ climatologia/serveis-i-dades-climatiques/normalsclimatiques-recents/> [accessed 28 October 2019].

Minitab Inc., 2012. Minitab Statistical Software Version 17.2.1. Minitab Inc., State College, PA. URL $<$ http://www.minitab.com/> [accessed 30 October 2019].

O'Brien, P., Acharya, U., Alghamdi, R., Niaghi, A.R., Sanyal, D., Wirtz, J., Daigh, A.L.M., DeSutter, T.M., 2018. Hydromulch application to bare soil: soil temperature dynamics and evaporative fluxes. Agricultural \& Environmental Letters, 3, 180014. DOI: 10.2134/ael2018.03.0014

Pramanik, P., Bandopadhyay, K.K., Bhaduri, D., Bhattacharyya, R., Aggawal, P., 2015. Effect of mulch on soil thermal regimes - a review. International Journal of Agriculture, Environment and Biotechnology, 8, 3, 645-658.
Qiu, G.Y., Ben-Asher, J., 2010. Experimental determination of soil evaporation stages with soil surface temperature. Soil Science Society of America Journal, 74, 1, 13-22.

Rico Hernández, J.R., Navarro Pedreño, J., Gómez Lucas, I., 2016. Evaluation of plant waste used as mulch on soil moisture retention. Spanish Journal of Soil Science, 6, 2, 133-144.

SAS, 2013. Statistical Analysis Systems, Software Version 9.4. SAS Institute Inc., Cary, North Carolina, USA.

Saxton, K.E., Rawls, W.J., Romberger, J.S., Papendick, R.I., 1986. Estimating generalized soil-water characteristics from texture. Soil Science Society of America Journal, 50, 4, 1031-1036.

Shogren, R.L., 2000. Biodegradable mulches from renewable resources. Journal of Sustainable Agriculture, 16, 4, 33-47.

Shumova, N., 2013. Evapotranspiration changes in the foreststeppe and steppe zones under soil mulching. Journal of Hydrology and Hydromechanics, 61, 1, 140-145.

Sintim, H.Y., Bandopadhyay, S., English, M.E., Bary, A.I., DeBruyn, J.M., Schaeffer, S.M., Miles, C.A., Reganold, J.P., Flury, M., 2019. Impacts of biodegradable plastic mulches on soil health. Agriculture, Ecosystems and Environment, 273, 36-49.

Steinmetz, Z., Wollmann, C., Schaefer, M., Buchmann, C., David, J., Tröger, J., Muñoz, K., Frör, O., Schaumann, G.E., 2016. Plastic mulching in agriculture. Trading short-term agronomic benefits for long-term soil degradation? Science of the Total Environment, 550, 690-705.

Teng, J., Yasufuku, N., Liu, Q., Liu, S., 2013. Analytical solution for soil water redistribution during evaporation process. Water Science \& Technology, 68, 12, 2545-2551.

Warnick, J.P., Chase, C.A., Rosskopf, E.N., Simonne, E.H., Scholberg, J.M., Koenig, R.L., Roe, N.E., 2006. Weed suppression with hydramulch, a biodegradable liquid paper mulch in development. Renewable Agriculture and Food Systems, 21, 4, 216-223.

Zhang, C., Li, L., Lockington, D., 2015. A physically based surface resistance model for evaporation from bare soils. Water Resources Research, 51, 1084-1111.

Zribi, W., Aragüés, R., Medina, E., Faci, J.M., 2015. Efficiency of inorganic and organic mulching materials for soil evaporation control. Soil \& Tillage Research, 148, 40-45.

Received 16 December 2019 Accepted 2 May 2020 